\title{
Population-level zoogeomorphology: the case of the Eurasian badger
}

(Meles meles L.).

\author{
Martin A. Coombes ${ }^{a^{*}}$ and Heather A. Viles ${ }^{a}$ \\ axford Rock Breakdown Laboratory, School of Geography and the Environment, University of Oxford, \\ South Parks Road, Oxford, OX1 3QY, UK. "Corresponding author: Martin.Coombes@ouce.ox.ac.uk
}

\begin{abstract}
The zoogeomorphological impact of burrowing animals varies in time and space as a result of the particular life-history traits of the organisms involved, the patchy distribution of habitat resources, and fluctuations in population size. Such ecological complexity presents a major challenge for biogeomorphologists wishing to upscale from individuals to populations.
\end{abstract}

Using a unique ecological dataset for Eurasian badgers (Meles meles L.) in Wytham Woods, Oxfordshire, UK, we show that direct zoogeomorphological impact (soil displacement during sett excavation) is constrained by fluctuations in overall population size. Modelled digging rates for individual badgers $\left(0.19-4.51 \mathrm{~m}^{3} \mathrm{yr}^{-1}\right)$ varied depending on the ecological function of the sett they are associated with, and we estimate that the whole population has displaced $304-601 \pm 72 \mathrm{~m}^{3}$ of soil during the construction of 64 setts. This represents an overall excavation rate of 6.7-19.4 $\mathrm{m}^{3}(6.0-17.5 \mathrm{t}) \mathrm{yr}^{-1}$ in sett areas, or $1.42-4.12 \mathrm{~g} \mathrm{~m}^{-2} \mathrm{yr}^{-1}$ when averaged over the whole 424 ha woodland.

As well as direct soil displacement, badger digging exposes material that is initially susceptible to erosion by water relative to undisturbed, litter-covered soils. Over time, setts become stabilized, representing unique landforms that persist in the landscape for decades to centuries.

KEY WORDS: Burrowing, biogeomorphology, bioturbation, Meles meles, ecosystem engineering, Wytham Woods 


\section{(1)}

\section{Introduction}

Many animals dig underground nests and burrows for refuge from predators and the provision of safe conditions for the birth and rearing of young (Kinlaw, 1999; Meadows, 1991; Reichman \& Smith, 1990; Whitford \& Kay, 1999). Through these activities fossorial (burrowing) animals can displace and deposit large quantities of sediment ('spoil') at the surface in mounds or heaps. These conspicuous surface features have received sustained interest from geomorphologists wishing to quantify the impact of living organisms on the landscape (e.g., Viles, 1988; Butler, 1995).

As well as direct spoil displacement, burrowing animals mix, aerate, and compact sediment (Hole, 1981). This bioturbation (or 'biopedturbation', Whitford \& Kay, 1999) means that soil nutrient and organic content, water-holding capacity, infiltration and hydrological conductance, $\mathrm{pH}$, color, texture, structure, and stability can all vary significantly when compared with undisturbed soils (Carlson \& White, 1988; Eldridge, Koen, Killgore, Huang, \& Whitford, 2012; Gabet, Reichman, \& Seabloom, 2003; Garkaklis, Bradley, \& Wooller, 2004; Wilkinson, Richards, \& Humphreys, 2009). The consequent impacts of burrowing and digging on soil erodibility and sediment transport rates are of particular interest to geomorphologists (e.g., Black \& Montgomery, 1991; Neave \& Abrahams, 2001; Yoo, Amundson, Heimsath, \& Dietrich, 2005).

At the same time, burrowing animals are recognized as being ecologically important as ecosystem engineers (Jones, Lawton, \& Shachak, 1994, 1997); the physical impacts of organisms (the primary focus for geomorphologists) often have additional consequences (feedbacks) for the distribution, interaction, survival, and evolutionary fitness of other organisms via the creation—and subsequent decay—of physical habitat resources (Corenblit et al., 2011; Cuddington, Byers, Wilson, \& Hastings, 2007; Hastings et al., 2007; 
Jones, 2012; Wright \& Jones, 2006). In this respect, many studies have demonstrated the importance of burrowing and digging for nutrient cycling, seed dispersal, vegetation community dynamics, intra- and inter-species interactions, biodiversity, ecosystem resilience to environmental change, and habitat restoration and management (e.g., Byers et al., 2006; Eldridge, 2011; Eldridge et al., 2012; Eldridge, Whitford, \& Duval, 2009; Fleming et al., 2014; Hansell, 1993; James, Eldridge, \& Moseby, 2010; Kinlaw \& Grasmueck, 2012; Maestre et al., 2012; Martin, 2003; Meadows \& Meadows, 1991; Zaitlin \& Hayashi, 2012).

On-going integration of biogeomorphology and ecosystem engineering (e.g., Butler \& Sawyer, 2012) is fuelling important conceptual debates about the significance of organisms' physical impacts at increasingly large spatial and temporal scales (e.g., Corenblit, Gurnell, Steiger, \& Tabacchi, 2008; Jones, 2012; Viles, 2012). A major challenge here is a general lack of suitable data to quantify animal impacts beyond the scale of individuals. This is critical, however, if the significance of the collective impacts of individuals (forming populations) and whole ecological communities are to be fully appreciated at a landscape scale (Coombes, in press; Dietrich \& Perron, 2006; Naylor, Viles, \& Carter, 2002; Reinhardt, Jermlmack, Cardinale, Vanacker, \& Wright, 2010). Recent work has demonstrated the potential for modelling to address these issues (e.g., Gabet, Perron, \& Johnson, 2014; Yoo et al., 2005), but the availability of suitable ecological data remains a major constraint.

\section{Badgers as geomorphic agents}

All ten species of badger dig and inhabit burrows (Long \& Killingley, 1983). The Eurasian badger (Meles meles L.) is unique among these, however, in that it has evolved sociality and communal living in underground burrow systems, called setts (Kruuk, 1989). Eurasian 
81 badgers live in defended territories as part of a social group, usually occupying one main

82 sett and several smaller subsidiary setts ('outliers' or 'annexes') that have different

83 functions including resting, winter sleeping, and breeding and rearing of cubs (Kaneko,

84 Newman, Buesching, \& Macdonald, 2010; Kruuk, 1978a, 1989; Neal, 1977; Roper, 1992a;

85 Thornton, 1988). A single sett may be inhabited by up to 35 individuals at any one time

86 (Woodroffe \& Macdonald, 1993); however, the size of a sett is not related to the size of the 87 social group it currently supports (Kruuk, 1978a; Neal, 1977) but is more a function of its use as a main or subsidiary sett, its age, the substrate it is dug in, and the life-history traits (including sex, fecundity, and sett fidelity) of all the occupants that have ever lived there

90 (Dunwell \& Killingley, 1969; Kruuk, 1989; Neal \& Roper, 1991; Roper, 1992a; Stewart, 91 Bonesi, \& Macdonald, 1999).

Internal sett architecture is highly variable (Roper, 1992b) but tunnels are typically dug in a zone that extends from the surface to 1.5-2 m vertical depth (Kaneko et al., 2010). When excavating tunnels, badgers loosen earth with the forelimbs before bringing the hind legs forward and backing out to push soil up to the surface, often kicking spoil clear of the burrow entrance in a downslope direction (Neal \& Cheeseman, 1996). The progressive accumulation of spoil (across generations) forms surface mounds (Figure 1) reported to exceed $30-40 \mathrm{~m}^{3}$ in volume in some cases, and which often coalesce to form larger surface features, hereafter referred to as 'sett surface complexes'. A similar process

101 ('cannibalisation') has been reported for pocket gopher mounds (Gabet et al., 2014). Three 102 to ten entrance holes is fairly typical for a main sett, although setts with almost 200 103 entrances have been reported (Roper, 1992a, b). The re-excavation of old entrance holes, extension of existing tunnels, and excavation and connection of new chambers to the surface exposes sediment to surface processes in occupied areas. As well as digging to 
construct burrows, badgers may dig shallow foraging pits (or 'scrapes', Wilkinson et al., 2009) when searching for earthworms and other foodstuffs (Kruuk, 1978b).

Despite a vast ecological literature on the burrowing behavior of this species, we are aware of only one study that has explicitly focused on the geomorphological significance of M. meles (Voslamber \& Veen, 1985). The potential of Eurasian badgers as physical ecosystem engineers has too only been acknowledged relatively recently, in reference to soil nutrient dynamics and plant communities (Kurek, Kapusta, \& Holeksa, 2014). Here, we use field observations alongside a multi-decadal dataset for a population of $M$. meles in Wytham Woods, Oxfordshire, UK, to: (1) evaluate the relationship between population dynamics and landscape-scale digging activity; (2) quantify the direct zoogeomorphological impacts of badgers at this site by estimating the volume of soil displaced during the construction of setts, and; (2) evaluate the indirect zoogeomorphological significance of badger burrowing by characterizing the erodibility of spoil material once deposited at the surface.

\section{Study site}

Wytham Woods (OS SP 462 080) occupy 424 ha of land $5 \mathrm{~km}$ north-west of the City of Oxford, UK (Figure 2). The woods lie over two outlying hills of the Cotswold Escarpment (Wytham Hill and Seacourt Hill) varying in altitude from 60-165 m above sea level (Macdonald, Newman, Dean, Buesching, \& Johnson, 2004). Geology consists of Middle Jurassic Coral Rag topped with clayey soils from the Sherbourne and Morton series that rest on Lower Calcareous Grit sands. This characteristically orange-yellow sand encircles the two hills (Figure 2) and is the preferred digging medium for the badgers (Hofer, 1988; Kruuk, 1978a) (Figure 3a-b). 
132 The Wytham badgers have been studied intensively since the 1970s (first described in

133 detail by Kruuk, 1978a, b) and a comprehensive trapping program was initiated in 1987

134 (four trappings per year) providing detailed life-history data for all individual badgers and

135 setts (Macdonald \& Newman, 2002; Macdonald, Newman, Nouvellet, \& Buesching, 2009).

136 Here we use data collected between 1987 and 2004 (a 17-year period). As of 2004, the

137 population consisted of 213 badgers (190 adults), representing the highest density in the

138 world (around 38 per $\mathrm{km}^{2}$ ). Setts had a density of about 70 per $\mathrm{km}^{2}$, consisting of 64

139 named main setts (which we focus on in this study) and an additional 215 smaller digging

140 sites, all organized into 24 independent social groups (Macdonald et al., 2004) (Figure 2).

\section{Methods}

\section{Population-level zoogeomorphology}

144 As a means of assessing relationships between population dynamics and direct 145 zoogeomorphic activity (i.e., sett excavation), the years in which setts were first recorded were determined from annual survey records (from 1987 onwards). The number of newly constructed setts was then compared to annual population data from the trapping database (Department of Zoology, University of Oxford).

\section{Direct impacts: sett excavation volume}

151 The total volume of soil moved during excavation of all named setts $(n=64)$ was

152 estimated using two different modelling approaches, allowing for comparison between

153 methods. First, predictive regression models were used to estimate sett subsurface

154 volume from measurements of sett surface area made in the field. Second, 3D models of 155 two sett surface complexes were used to derive 'average digging rates' for individual 156 badgers, which were subsequently extrapolated for the whole population. Each approach 157 is outlined, in turn, in the following sections. 
Method 1: Estimating excavated soil volume from sett surface area

160 Around half of all named setts were located during summer $2005(n=29)$ and their surface 161 areas measured as the extent of existing mounds and spoil. Observations of the influence 162 of setts on the local topography were also made. In order to derive surface area estimates 163 for the remaining unvisited setts $(n=35)$, a predictive model was constructed using a 164 variety of ecological parameters (available for all setts) from the trapping database (Table 165 1) and multiple regression. This 'area model' (eq. 1) had statistically significant predictive 166 power for the surface area of visited setts $\left(R^{2}=0.73, p<0.001\right)$ :

$$
A=8.7 a+1.0 X_{y r}+15.5 c-7.2 u-20.7
$$

where $A=$ sett surface area $\left(\mathrm{m}^{2}\right), a=$ sett age (years), $X_{y r}=$ excavation years, $c=$ sett fecundity (number of cubs), and $u=$ unique residency (number of adults) (see Table 1 for full explanation of these parameters).

172 Surface area data (both measured and modelled) were then used to estimate the subsurface volume of setts using a simple 'volume model' (eq. 2). This model was derived from existing area/volume data for 19 manually excavated setts published in Roper (1992b). This model had a statistically significant predictive power for sett subsurface volume $\left(R^{2}=0.87, p<0.001\right)$ :

$$
V=0.03 A-0.14
$$

where $V=$ sett subsurface volume $\left(\mathrm{m}^{3}\right)$ and $A=$ minimum sett surface area $\left(\mathrm{m}^{2}\right)$.

Method 2: Estimating excavated soil volume from individual digging rates

181 The second approach used to estimate soil displacement volumes involved calculation of an average 'per badger excavation rate' $(e)$, which was then extrapolated for all members of the population, using the following principles. First, the amount of material constituting a 
184

185

sett surface complex was assumed to result from the cumulative actions of all individual badgers that have ever been resident there, excluding cubs as they do not dig (Neal \& Cheeseman, 1996), thus:

$$
E=E_{1}+E_{2}+E_{3} \ldots E_{n}
$$

where $E=$ total sett excavation volume, $E_{1}=$ excavation by badger $1, E_{2}=$ excavation by badger 2 , etc. Second, the number of years each adult badger has been resident at a sett was used to define the potential number of 'excavation years' it has contributed to its construction:

$$
E_{n}=e_{n} r_{n}
$$

where $E_{n}=$ total soil excavated by individual $n, e_{n}=$ annual excavation by badger $n$, and $r_{n}$ $=$ residency of individual $n$ at a sett (in years). Thus, the total number of 'excavation years' $\left(X_{y r}\right)$ contributing to the construction of any sett can be defined as the cumulative total of the residency (in years) of all adult badgers that have ever lived there, thus:

$$
X_{y r}=\sum_{n} r_{n}
$$

Note that $X_{y r}$ will always be greater than the age of a sett where occupancy has been greater than 1, as the model assumes all resident adult badgers contribute to digging. Finally, assuming that individuals dig at a constant rate (see discussion), the total excavated volume of any sett $(E)$ is estimated as a product of the total excavation years $\left(X_{y r}\right.$, eq. 5$)$ and the average badger excavation rate (e), thus:

$$
E=e X_{y r}
$$

In order to determine $E$ for all main setts (using eq. 6), the number of excavation years $\left(X_{y r}\right)$ was determined in each case from the trapping database (using eq. 5), and representative values of $e$ were calculated using the rearranged formula:

$$
e=\frac{E}{X_{y r}}
$$


where $E$ was determined for two different sett complexes using topographic field surveys and 3-dimensional surface models, outlined below. An excavation volume $(E)$ for all 64 named setts was then estimated (eq. 6) using the calculated values of $e$ for the two

211 reconstructed setts. This approach is unique in accounting for potential differences in the 212 contribution of individuals to digging occurring as a function of residency time-an

213 important consideration for bioconstructions built by social groups and successive 214 generations of individuals.

216 For the 3D reconstructions, 'Pasticks Outlier' (PO) and 'Mac Bracken' (MB) setts were 217 chosen for being in contrasting areas of the woods (Figure 2), having easy access, and 218 being of known age ( $\mathrm{PO}=10$ years, $\mathrm{MB}=12$ years). In both cases, relative spot-heights 219 over the sett surface were calculated in a grid $\left(1 \mathrm{~m}^{2}\right.$ resolution) using ranging poles and a 220 clinometer. Relative spatial reference coordinates and calculated spot heights were then 221 imported into GIS software (ArcMap) in XYZ format and Triangulated Irregular Network models (TINs) generated using $0.1 \mathrm{~m}$ interpolated contours. To calculate the excavation volume $(E)$ of both setts (to be used in eq. 7), all positive and negative elevation change components in the models relative to a 'pre-disturbance' plane (constructed from surveyed edge-points) were summed using cut-fill analysis within ArcMap Spatial Analyst.

Indirect impacts: sett surface cover and spoil erodibility

Surface cover

229 Percent cover $( \pm 5 \%)$ of bare soil, vegetation, litter, and stones was estimated for four 230 different patches on and around sett complexes (spoil mound tops, mound flanks, inter231 mound areas, and control areas). Measurements were made across two main setts for 232 comparison (Mac Bracken and The Mount, chosen mainly for access) in 20 quadrats (1 $233 \mathrm{~m}^{2}$ ) per patch. Data were compared using ANOVA to determine whether cover type varied 
as a function of patch type. 'Patch' was a fixed factor (four levels) and 'cover type' was nested within 'patch' (three levels; stone cover data were excluded due to a high proportion of zero values). Data heteroscedasticity was corrected for using square-root data transformation.

\section{Soil properties}

As a comparative measure of the resistance of sett surfaces and control soils to erosion by water and wind, penetration resistance (unconfined strength) was determined using a hand-held penetrometer at three setts (The Mount, Radbrook Common Outlier, and Mac Bracken). The force required $\left(\mathrm{kg} \mathrm{cm}^{-2}\right)$ to insert the probe to a depth of $5 \mathrm{~cm}$ was measured 30 times in four patches (fresh spoil, older mound flanks, badger paths used to reach foraging grounds, and control areas). Data were square-root transformed and compared using a one-way ANOVA (four levels of patch type).

Water Drop Penetration Time (WDPT) was also determined as a measure of soil surface tension and hydrophobicity (Doerr, 1998). For this, fifteen drops of distilled water were applied to levelled surfaces of air-dried soil samples collected from different sett patches (fresh spoil, crusted spoil, the flanks and bases of older mounds, and adjacent control areas). The time taken for droplets to fully infiltrate was then recorded. Wet and dry aggregate stability were also determined by carefully submerging individual aggregates (1 $\mathrm{cm}$ in diameter) in distilled water and recording the time taken for partial and complete breakdown. Finally, composition and grain size analyses were undertaken for surface soil samples (all $<5 \mathrm{~cm}$ depth, $n=5$ ) from different sett patches (fresh spoil, crusted spoil, mound flank, mound base, and control areas) following standard wet and dry sieving techniques. Fine soil fractions were analyzed using laser granulometry. 


\section{Results and Discussion}

\section{Population-level zoogeomorphology}

262 The badger population in Wytham Woods has shown distinct periods of growth and 263 decline; the population tripled between 1987 and 1996, declined in the late 1990s, followed 264 by a period of further growth (Macdonald \& Newman, 2002; Macdonald et al., 2009). More recent trends have been related to climatic variability, most notability changes in rainfall and its impact on the availability of earthworms - the favored food stuff for the Wytham population (Macdonald et al., 2010; Nouvellet, Newman, Buesching, \& Macdonald, 2013; Noonan et al., 2014).

Figure 4 illustrates a clear relationship between minimum population size (number of unique badgers trapped each year) and the number of newly dug setts between 1987 and 2004. Over this period the strongest correlation is achieved factoring in a 3-year lag between population size and sett establishment $\left(R^{2}=0.67, p=0.006\right)$. A similar relationship was reported by Macdonald \& Newman (2002) for the period between 1987 and 1996. Macdonald et al. (2004) also note that a peak in badger numbers occurred six years before a proliferation of new setts being excavated. This lag may reflect the time taken for cub cohorts to reach adulthood (and thus able to contribute to sett excavation) or the time required for the complex re-organization of social groups that precedes the establishment of new clans and setts (Macdonald et al., 2004).

It follows that long-term population trends will be reflected in a non-uniform rate of soil displacement by badgers (in terms of sett excavation, and possibly population-scale 283 foraging effort), and that factors affecting future population size will have subsequent 284 (lagged) implications for soil displacement and topographic change. This includes climate change, the zoogeomorphological (and broader biogeomorphological) implications of 
which remain understudied (see Butler, 2012). For many burrowing species, changes in

287 climate and weather patterns are likely to have major ecological consequences for 288 resource-dependent populations. For example, climate-driven changes in food availability 289 are likely to have zoogeomorphological and well as ecological consequences by affecting 290 the spatial density, temporal frequency, and intensity of foraging activity, and the number 291 of individuals engaged in digging activity (e.g., Garkaklis et al., 2004; Hall \& Lamont, 2003; 292 Johnson, Jetz, \& Macdonald, 2002; Macdonald \& Newman, 2002; Macdonald et al., 2004; 293 Nouvellet et al., 2013; Yair \& Rutin, 1981). The Wytham badgers represent one of the first 294 examples to clearly demonstrate the importance of population dynamics in driving zoogeomorphological activity at the local and landscape scale, over a decadal timescale.

\section{Direct zoogeomorphological impacts of badgers}

Setts as bioconstructions

299 Setts are distinctive bioconstructions in Wytham Woods. Whilst they vary greatly in lateral 300 and vertical extent, Eurasian badger setts have significantly altered local topography. The 301 height of sett mounds varied in the order of $0.2-2 \mathrm{~m}$ above the local topographic surface 302 depending on sett age, underlying slope angle, position on slopes, and the presence of 303 obstructions such as trees (Table 2). Sett dimensions are therefore comparable with 304 landforms created by other noted fossorial mammals, including gopher mounds and 305 wombat warrens (compared in Table 3).

307 In the steeper northern part of the woods, badgers have dug perpendicularly into slopes 308 (to reach the looser grit sand layer) resulting in characteristic stepped profiles following the 309 downslope movement of spoil. Similar stepped topography has been reported for gophers 310 (Thorn, 1978) and rabbits (Rutin, 1992). In the flatter southern areas of the woods, 311 badgers dig vertically into the ground to reach the sand layer, giving more characteristic 
312 'doughnut' morphology to mounds. Collapsed burrows and entrances were noticeable

313 features of some setts (Figure 3c), creating localized surface depressions (typically $<0.5$

$314 \mathrm{~m}$ depth) that had been re-excavated in some instances. Similar topographic features have

315 also been reported for rabbit warrens (Eldridge \& Myers, 2001), grizzly bear dens (Butler,

316 1992, 1995), and puffin burrows (Furness, 1991).

318 Excavated soil volume 1: estimates from sett surface area

319 The combined surface area of 29 visited setts was $5,832 \mathrm{~m}^{2}$. Doubling this gives a crude 320 estimate of the total area modified by badgers during the construction of all 64 named 321 setts $\left(11,664 \mathrm{~m}^{2}\right)$. This is equivalent to just $28 \mathrm{~m}^{2} \mathrm{ha}^{-1}$ across the whole woodland site and 322 illustrates the highly non-uniform spatial distribution of setts (e.g., Figure 2). This estimate 323 compares remarkably well to the total surface area calculated using the area regression 324 model (eq. 1) $\left(11,454 \mathrm{~m}^{2}\right.$ or $27 \mathrm{~m}^{2}$ ha-1). These values represent minimum estimates as of 3252004 , excluding addition smaller diggings.

327 Using these surface area data in the volume model (eq. 2), the estimated total volume of 328 soil excavated during construction of named setts at Wytham is $304.4 \mathrm{~m}^{3}$ (Table 4). This 329 excludes five setts for which modelled volumes were slightly negative due to initially small 330 values of $A$. This estimate is equivalent to about $274 \mathrm{t}$ based on a minimum indicative soil 331 bulk density of $0.9 \mathrm{Mg} \mathrm{m}^{-3}$ (Butt et al., 2009). This represents soil displacement rates of 332 between 0.1 and $1.5 \mathrm{~m}^{3} \mathrm{yr}^{-1}$ at individual setts, or a total of between 6.7 and $9.8 \mathrm{~m}^{3} \mathrm{yr}^{-1}$ 333 (6.0-8.8 t) for all setts, depending on whether those of unknown age (already present in 334 the first survey of the site in 1972 as reported by Kruuk, 1978a) are included in the 335 calculations (Table 4). The average estimated excavation volume for an individual sett $(E)$ 336 is $4.7 \mathrm{~m}^{3}$ (about $4.2 \mathrm{t}$ of soil), but ranges from just $0.2 \mathrm{~m}^{3}$ up to a maximum of $27.8 \mathrm{~m}^{3}(25 \mathrm{t}$ 337 of soil) for the largest sett ('Great Oak', Table 2). 
339 Excavated soil volume 2: extrapolation from individual digging rates

340 Reconstructions of Mac Bracken (MB) and Pasticks Outlier (PO) sett complexes are 341 shown in Figure 5a-b. Cut-fill analyses gave total estimated soil excavation volumes of $34226.0 \mathrm{~m}^{3}(23.4 \mathrm{t})$ and $19.3 \mathrm{~m}^{3}(17.4 \mathrm{t})$ for these two setts, respectively. This is equivalent to 343 an excavation rate of $2.2 \mathrm{~m}^{3} \mathrm{yr}^{-1}$ at $\mathrm{MB}$ and $1.9 \mathrm{~m}^{3} \mathrm{yr}^{-1}$ at $\mathrm{PO}$.

345 Notably, the excavation volumes for MB and PO derived from the 3D reconstructions are 346 much greater than those calculated using the regression models-by a factor of more than 3473 (Table 5). This may be attributed to over-estimation by the reconstruction technique as 348 this approach assumes the whole sett complex is composed only of soil; in reality, larger 349 badger sett complexes may include bedding material (grass, leaves, etc. used to line 350 chambers) that is incorporated into spoil during periods of sett maintenance (Neal \& 351 Cheeseman, 1996, Figure 3d). Even slight inaccuracies in the underlying slope plane may 352 also influence cut-fill estimates; sensitivity tests using artificially lowered edge point data 353 indicated that survey inaccuracies in the order of $2 \mathrm{~cm}$ yield errors in volume estimates of 354 about $12 \%$. Excavation volumes calculated using the area and volume regression models 355 (eq. 1 and eq. 2) are therefore probably better as conservative minimum estimates.

Nevertheless, 3D reconstruction provides a unique means of estimating individual digging rates $(e)$ that can be extrapolated up to the whole population-something that has proved extremely difficult in zoogeomorphological studies. Thus, between 1993 and 2004, 10

360 different badgers contributed 17 excavation years $\left(X_{y r}\right.$, eq. 5$)$ to the construction of MB 361 sett. Based on a volume of $26.0 \mathrm{~m}^{3}$ derived from the 3D model, the average annual excavation rate per badger (e) at this sett is $1.53 \mathrm{~m}^{3} \mathrm{yr}^{-1}$ (eq. 7, Table 4). This compares with estimates of annual soil excavation by individual pocket gophers $\left(0.5-1.7 \mathrm{~m}^{3}\right)$ 
364

365

reported by Cox \& Allen (1987). In marked contrast, a significantly higher number of excavation years at PO (104 years by 41 unique adult badgers since 1995) yields a much smaller value of $e$, just $0.19 \mathrm{~m}^{3} \mathrm{yr}^{-1}$, based on a soil volume of $19.3 \mathrm{~m}^{3}$ (Table 4). This lower value compares remarkably well with the average estimate of $e$ derived using the surface area/volume regression models $\left(0.21 \mathrm{~m}^{3} \mathrm{yr}^{-1}\right)$ (Table 4).

By substituting these two values of e ( 0.19 for $\mathrm{PO}$ and 1.53 for $\mathrm{MB})$ into eq. 6 for each sett, the total excavation volume for the 64 main setts is estimated to be between $601.4 \mathrm{~m}^{3}(541$ t) and 4,842.5 $\mathrm{m}^{3}(4,358 \mathrm{t})$. These calculations represent very different annual soil displacement rates of 13.1-19.4 $\mathrm{m}^{3} \mathrm{yr}^{-1}$ and 113.3-156.2 $\mathrm{m}^{3} \mathrm{yr}^{-1}$, respectively, depending on whether setts $>31$ years old are included. Such a large difference in estimated digging rates is likely explained by the ecological functions of these two setts. In particular, the fecundity of female badgers (see Table 1) from MB is 1.58 (Table 2), which is the second highest of all setts and significantly higher than the population average of 0.44 .

Furthermore, the sex ratio of all previous residents at MB sett is heavily skewed towards females (Table 2). This indicates that Mac Bracken has functioned as a breeding annex to which females from the social group in this area of the woods ('Marley Main') move periodically to give birth (Revilla, Palomares, \& Fernández, 2001; Roper, 1992a; Roper, Ostler, Schmid, \& Christian, 2001).

Setts with high fecundity (such as MB) are expected to have more chambers than other setts_-and therefore likely higher excavation rates_as cubs are thought to be raised in isolation from other members of the social group (Cresswell, Harris, Cheeseman, \& Mallinson, 1992; Kruuk, 1989). Furthermore, the topographies of breeding annexes likely reflect greater incorporation of bedding material, as bedding collection and maintenance behaviors are more frequent and intensive at these setts (Kaneko et al., 2010). By 
390 functioning as a breeding annex, a few individuals resident at Mac Bracken (MB) sett 391 appear to have dug significantly more earth than the many more individuals at Pasticks 392 Outlier (PO), and over a similar period of time (10 and 12 years, respectively). Similarly, 393 'The Mount' sett is unusually large relative to its number of excavation years and has the

394 highest fecundity of any sett (Table 2). These observations suggest that the amount of soil 395 displaced during the construction and maintenance of Eurasian badger setts is heavily 396 influenced by its particular social function and the reproductive life-history traits of its 397 residents (e.g., Stewart et al., 1999). This is a factor that may well have bearing on the 398 geomorphological impacts of other burrowing animals, particularly those living in social 399 groups.

400

401 With all this in mind, we regard the very high digging rate $(e)$ calculated for Mac Bracken 402 sett as a probable exception. We therefore favor our more conservative volume 403 estimations based on: (1) the digging rate $(e)$ derived from the reconstruction of Pasticks 404 Outlier sett $\left(0.19 \mathrm{~m}^{3} \mathrm{yr}^{-1}\right.$ per badger $)$, and (2) the surface area/volume regression models. 405 These preferred methods yield an estimated total soil excavation volume for the 64 named 406 setts in Wytham Woods of 304.4-601.4 $\mathrm{m}^{3}$ (as of 2004), representing a local digging rate 407 of $6.7-19.4 \mathrm{~m}^{3}(6.0-17.5 \mathrm{t})$ per year at sett sites (Table 4). Averaged over the whole 408 woodland (424 ha) this equates to a sediment production rate of $1.42-4.12 \mathrm{~g} \mathrm{~m}^{-2} \mathrm{yr}^{-1}$. 409 Encouragingly, our conservative estimate lies within the range previously reported for 410 Eurasian badgers in the Belgian Ardennes $\left(0.05-12.9 \mathrm{~g} \mathrm{~m}^{-2} \mathrm{yr}^{-1}\right.$, Table II in Voslamber and 411 Veen, 1985).

413 Indirect zoogeomorphological impacts of badgers

414 Soil surface cover 
415 Soil cover type varied significantly between sett surface patches (ANOVA $p<0.000$, Table

416 6). Post-hoc comparisons (Tukey tests) showed that sett mound tops and flanks had

417 significantly more bare soil than inter-mound and control areas, which had significantly

418 more litter $(p<0.05$, Figure 6). Eldridge \& Myers (2001) report similar patterns for mounds

419 of the European rabbit (Oryctolagus cuniculus L.) associated with disturbance by digging

420 and trampling. Litter was also observed to accumulate in areas of digging nearby setts,

421 such as shallow foraging digs and latrines (e.g., Figure 3e), but these were not measured

422 directly in this study. The boundary between mound flanks and inter-mound areas was

423 typically well-defined (also observed for European rabbit warrens, Eldridge \& Myers, 2001)

424 and reflects the shedding of litter from mounds and its accumulation around the edges of

425 sett complexes (e.g., Figure 3f).

427 Vegetation cover did not vary significantly between sett patches although clumps of 428 juvenile plants, especially dog's mercury (Mercurialis perennis) and common nettle (Urtica

429 dioica), were sometimes present on the flanks of spoil mounds (e.g., Figure 3g) whilst

430 typically absent from litter-covered control areas. In a recent study in Poland (Kurek et al., 4312014 ) digging by M. meles and foxes (Vulpes vulpes) was found to cause a shift in plant 432 community composition and species richness relative to undisturbed areas. This was 433 associated with changes in soil physical and chemical properties and endozoochorous 434 seed dispersal. Digging by other mammals such as pocket gophers and rabbits also alters 435 plant community composition to varying extents depending on the frequency of soil 436 disturbance and reworking (Eldridge \& Myers, 2001; Huntly \& Reichman, 1994). A detailed 437 assessment of the impacts of M. meles on plant communities in Wytham Woods is yet to 438 be undertaken. 
440 Stoney material (the Coral Rag through which the badgers dig to reach the preferred 441 sandy soil below) was found exclusively in areas of badger disturbance (mound tops, 442 flanks, and inter-mound areas) whilst completely absent from control areas (Figure 6). The 443 relative occurrence of the Rag is partly dependent on whether setts were built on slopes or 444 flat ground, and local variations in the thickness and depth of the Rag and grit layers 445 (Macdonald et al., 2004). Stones were typically graded by size on spoil mound slopes, as 446 larger stones roll further under gravity during excavation and when mobilized by runoff 447 flows (e.g., Figure 3h). Hansen and Morris (1968) suggest that the presence of rock or 448 large stones may inhibit burrowing by pocket gophers, but badgers are clearly able to 449 manage surprisingly large chunks of the Rag (mean dimensions were $10 \times 5 \times 4 \mathrm{~cm}$ and 450 the largest piece found in spoil was $25 \times 18 \times 16 \mathrm{~cm}, n=30)$.

Spoil erodibility

453 Martin (2003) suggests that bioturbated soils exhibit differences in infiltration and runoff 454 characteristics as a function of mineral, chemical, and organic composition, and properties 455 such as water repellency. Such variables affect erosion rates by altering the time required 456 for the infiltration of raindrops and the generation of surface flows capable of particle 457 entrainment and transport (e.g., Wessel, 1988). At Wytham, badger spoil had a higher 458 proportion of sand- (54\%) and gravel-sized (16\%) material compared to undisturbed soils 459 (32\% and $3 \%$, respectively) (Figure 7$)$, reflecting the displacement of grit sands and Coral 460 Rag from lower horizons. Unconfined compressive strength also varied significantly 461 between sett patches and control areas (ANOVA $p<0.000$, Table 7 ), with freshly-dug 462 spoil being 58\% weaker than control soils $(p=0.01$, Figure 8$)$. Water Drop Penetration 463 Times (WDPT) were less than one second for badger spoil compared to an average of 220 464 seconds for control soils $(n=20)$. Fresh spoil is therefore 'very hydrophilic' and 465 undisturbed soils 'moderately hydrophobic' according to the classifications of Bisdom, 
Dekker, \& Schoute (1993) and Doerr (1998). Similarly, aggregate breakdown was three orders of magnitude faster for fresh spoil in wet and dry stability tests compared to control soils (Figure 9).

Comparison of the relative grain size populations for fresh and crusted badger spoil (Figure 7) shows that once exposed at the surface, fresh spoil supplies fine sediment $(<$ $200 \mu \mathrm{m}$ in diameter) for erosion via rainsplash and surface wash (e.g., Borchard \& Eldridge, 2011). Indeed, removal of fines can occur within just a few precipitation events. Once in transport, material is moved to the periphery of mounds and may become incorporated into soils or move further downslope depending on the underlying gradient (Ellison, 1946; Gabet, 2000; Price, 1971; Wilkinson et al., 2009). In this way animal spoil can be a dominant source of material for erosion in many environments (e.g., Black \& Montgomery, 1991; Butler, 1995; Gabet, 2000; Thorn, 1978; Yair, 1995). As occupied setts remain free from a protective cover of litter (Figure 6) and have a greater proportion of mobile fine sediment exposed on their surfaces, digging by Eurasian badgers represents an important component of the sediment budget in the temperate woodlands they inhabit. Further direct comparisons of soil transport rates in control and sett areas would provide interesting data to support these observations.

In contrast to freshly-dug spoil, there is evidence of rapid stabilization via the removal of fines, and surface compaction and relaxation (Butler, 1995; Eldridge, 2004; Eldridge \& Myers, 2001; Eldridge \& Simpson, 2002). At Wytham, older sett surfaces were stronger than control soils ( $p=0.01$, Figure 8$)$, and while dried aggregates from older mounds broke down at a similar rate to crusted spoil, they were considerably more stable than fresh spoil in wet stability tests (Figure 9). Soil aggregates from the base of old mounds were most stable in dry and wet tests (Figure 9). Hard stony lag deposits were typical for 
492 older spoil (Figure 3h, Figure 6), which may be further hardened by cementation of muds

493 and clays following rainfall (Figure 8). Shedding of littler and stones from older mound

494 slopes is probably associated with the higher rates and deeper runoff flows that they

495 appear to generate. Of all sett patches, badger paths were most stable $(p=0.01$, Figure

496 8), attributed to compaction by generations of badgers during nightly foraging trips (Kruuk, 497 1978b, 1989). These paths may well represent preferential routes for surface water flows.

499 These observations indicate that badger sett bioconstructions represent landforms of 500 overall relative stability, but from which supply of fine material for subaerial processes 501 periodically occurs - at a rate determined by the frequency of badger disturbance. The fact 502 that badgers do not occupy all parts of their setts at any one time-around $80 \%$ of 1,130 503 entrance holes were actively being used in Wytham Woods in 2002 (Macdonald et al., 504 2004) - means that sett complexes consist of both relatively stable, older spoil deposits 505 and more recently dug, highly-erodible deposits.

\section{Conclusions}

508 Three decades of ecological data for a population of Eurasian badgers in Wytham Woods 509 have been used to assess local- and landscape-scale zoogeomorphic impacts in terms of 510 direct (sett excavation) and indirect (spoil erodibility) contributions to sediment

511 displacement, storage, and transport. Whilst our extrapolations assume equal individual 512 digging effort, we have, for the first time, been able to account for unevenness in 513 geomorphic impact arising from differences in individual sett fidelity. Further work is now 514 needed to develop and test these zoogeomorphological models in order to account for 515 more of the ecological complexity associated with animal populations. 
517 We estimate that individual badgers in Wytham Woods dig between $0.19-4.51 \mathrm{~m}^{3}$ of soil

518 per year depending on the sett they are associated with, the ecological function of that

519 sett, and the life-history traits of the individual. Taking values derived from the regression

520 models and reconstruction of Pasticks Outlier as being most representative, a minimum

521 total of 274-541 t of earth has been displaced during the construction of 64 setts (based

522 on 2004 data). This equates to a spatially-averaged sediment production rate of $1.42-4.12$

$523 \mathrm{~g} \mathrm{~m}^{-2} \mathrm{yr}^{-1}(6.0-17.5 \mathrm{t}$ per year in sett areas). Locally, badger setts themselves represent

524 unique landforms in European woodland habitats that appear to have been largely

525 overlooked in a geomorphological context compared to those of burrowing animals in other

526 environments (e.g., Gabet et al., 2014). The construction of badger setts—the

527 characteristics of which are largely driven by ecological factors-involves the direct and

528 often rapid displacement of significant amounts of soil.

530 Once excavated, the indirect geomorphological significance of setts (with respect to

531 sediment erosion and transport) depends on the relative proportion of new (freshly dug)

532 and older (stabilized) surfaces. Importantly, material brought to the surface by badgers

533 during the continual reworking, maintenance, and extension of setts creates patchy soil

534 conditions on which subaerial processes act at varying rates (e.g., Gabet et al., 2003).

535 Similar to other parts of Europe (e.g., Kurek et al., 2014), fresh badger spoil in Wytham

536 Woods had a higher proportion of sand, and our measurements show that this material

537 has lower structural stability than undisturbed soils and is susceptible to erosion by water.

538 Spoil mounds are quickly stabilized following the removal of fines (over a few rainfall

539 events) and the gradual development of cemented and compacted lag deposits. Well-

540 established badger setts are therefore relatively stable bioconstructions that persist in the

541 landscape for decades and probably centuries, but which periodically contribute highly-

542 erodible material to local sediment budgets. 
544 As well as presenting some of the first assessments of population-level zoogeomorphic 545 impacts, this study highlights the importance of both biotic and abiotic factors in 546 constraining the spatial and temporal patterns of digging by burrowing animals (e.g., Gabet 547 et al., 2014; Johnson et al., 2002; Macdonald, Mitchelmore, \& Bacon, 1996; Macdonald et 548 al., 2004; Obidziński, Pabjanek, \& Mędrzycki, 2013; Revilla et al., 2001). The availability of 549 suitable substrate, local topography, and density dependent interactions between social 550 groups are particularly important for Eurasian badgers. Such factors need to be identified 551 and quantified more fully in future zoogeomophological investigations if generalized, rule552 based models capable of evaluating landscape-scale impacts are to be developed and 553 constrained (e.g., Gabet et al., 2014; Schiffers, Teal, Travis, \& Solan, 2011). Data 554 generated from spoil measurements (volumes, mounding rates, decay rates, frequency of 555 reworking, etc.) are clearly critical to future work, but effort should also be made to collect 556 and utilize long-term ecological (i.e., population) and environmental data where available.

\section{Acknowledgements}

559 Dr. Christopher Newman, and members of WildCRU and the Wytham Badger Project 560 (Department of Zoology, University of Oxford) are thanked for permissions to access 561 Wytham Woods and for providing data from the Wytham Trapping Database. Dr. Parris Lyew-Ayee (University of the West Indies) is thanked for invaluable GIS assistance. 


\section{References}

566 Bisdom, E. B. A., Dekker, L. W., \& Schoute, J. F. T. (1993). Water repellency of sieve fractions from sandy soils and relationships with organic material and soil structure. Geoderma, 56, 105-118.

Black, T. A., \& Montgomery, D. R. (1991). Sediment transport by burrowing mammals, Marin County, California. Earth Surface Processes and Landforms, 16, 163-172.

Borchard, P., \& Eldridge, D. J. (2011). The geomorphic signature of bare-nosed wombats (Vombatus ursinus) and cattle (Bos taurus) in an agricultural riparian ecosystem. Geomorphology, 130, 365-373.

Butler, D.R. (1992). The Grizzly Bear as an erosional agent in mountainous terrain. Zeitschrift für Geomorphologie, 36, 179-189.

Butler, D. R. (1995). Zoogeomorphology: Animals and geomorphic agents. Cambridge, UK: Cambridge University Press.

Butler, D. R. (2012). The impact of climate change on patterns of zoogeomorphological influence: Examples from the Rocky Mountains of the Western U.S.A. Geomorphology, 157-158, 183-191.

Butler, D. R., \& Sawyer, C. F. (2012). Introduction to the special issuezoogeomorphology and ecosystem engineering. Geomorphology, 157-158, 1-5.

Butt, N., Campbell, G., Malhi, Y., Morecroft, M., Fenn, K., Thomas, M. 2009. Initial results from establishment of a long-term broadleaf monitoring plot at Wytham Woods, Oxford, UK. University of Oxford. Available at: http://www.eci.ox.ac.uk/publications/downloads/butt09-wythamwoods.pdf, accessed January 2014.

Byers, J. E., Cuddington, K., Jones, C. G., Talley, T. S., Hastings, A., Lambrinos, J. G., . . . Wilson, W. G. (2006). Using ecosystem engineers to restore ecological systems. Trends in Ecology \& Evolution, 21, 493-500. 
591 Carlson, D. C., \& White, E. M. (1988). Variations in surface-layer color, texture, pH, and phosphorus content across prairie dog mounds. Soil Science Society of America Journal, 52, 1758-1761.

594 Cincotta, R. P. (1989). Note on mound architecture of the black-tailed prairie dog. Great Basin Naturalist, 49, 621-623.

Coombes, M. A. (in press). Biogeomorphology. In D. Richardson, D. Marston, \& D. Butler (Eds.), International Encyclopedia of Geography: People, the Earth, Environment, and Technology. New York: Wiley-AAG.

Corenblit, D., Baas, A. C. W., Bornette, G., Darrozes, J., Delmotte, S., Francis, R. A., . . Steiger, J. (2011). Feedbacks between geomorphology and biota controlling Earth surface processes and landforms: A review of foundation concepts and current understandings. Earth-Science Reviews, 106, 307-331.

Corenblit, D., Gurnell, A. M., Steiger, J., \& Tabacchi, E. (2008). Reciprocal adjustments between landforms and living organisms: Extended geomorphic evolutionary insights. CATENA, 73, 261-273.

Cox, G. W., \& Allen, D. W. (1987). Soil translocation by pocket gophers in a Mima moundfield. Oecologia, 72, 207-210.

Cresswell, W. J., Harris, S., Cheeseman, C. L., \& Mallinson, P. J. (1992). To breed or not to breed: An analysis of the social and density-dependent constraints on the fecundity of female badgers (Meles meles). Philosophical Transactions: Biological

614 Dietrich, W. E., \& Perron, J. T. (2006). The search for a topographic signature of life. Nature, 439, 411-418. 
Doerr, S. H. (1998). On standardizing the 'Water Drop Penetration Time' and the 'Molarity of an Ethanol Droplet' techniques to classify soil hydrophobicity: A case study using medium textured soils. Earth Surface Processes and Landforms, 23, 663-668.

Dunwell, M. R., \& Killingley, A. (1969). The distribution of badger sets in relation to the geology of the Chilterns. Journal of Zoology, 158, 204-208.

Eldridge, D. J. (2004). Mounds of the American Badger (Taxidea taxus): Significant features of North American shrub-steppe ecosystems. Journal of Mammalogy, 85, 1060-1067.

Eldridge, D. J. (2011). The resource coupling role of animal foraging pits in semi-arid woodlands. Ecohydrology, 4, 623-630.

Eldridge, D. J., Koen, T. B., Killgore, A., Huang, N., \& Whitford, W. G. (2012). Animal foraging as a mechanism for sediment movement and soil nutrient development: Evidence from the semi-arid Australian woodlands and the Chihuahuan Desert. Geomorphology, 157-158, 131-141.

Eldridge, D. J., \& Myers, C. A. (2001). The impact of warrens of the European rabbit (Oryctolagus cuniculus L.) on soil and ecological processes in a semi-arid Australian woodland. Journal of Arid Environments, 47, 325-337.

Eldridge, D. J., \& Simpson, R. (2002). Rabbit (Oryctolagus cuniculus L.) impacts on vegetation and soils, and implications for management of wooded rangelands. Basic and Applied Ecology, 3, 19-29.

Eldridge, D. J., Whitford, W. G., \& Duval, B. D. (2009). Animal disturbances promote shrub maintenance in a desertified grassland. Journal of Ecology, 97, 1302-1310.

Ellison, L. (1946). The pocket gopher in relation to soil erosion on mountain range. Ecology, 27, 101-114. 
640 Fleming, P. A., Anderson, H., Prendergast, A. S., Bretz, M. R., Valentine, L. E., \& Hardy, G. E. S. (2014). Is the loss of Australian digging mammals contributing to a deterioration in ecosystem function? Mammal Review, 44, 94-108.

Furness, R. W. (1991). The occurrence of burrow-nesting among birds and its influence on soil fertility and stability. In P. S. Meadows \& A. Meadows (Eds.), The Environmental Impact of Burrowing Animals and Animal Burrows (pp. 53-65). Zoological Society of London Symposia 63: Clarendon Press, Oxford.

Gabet, E. J. (2000). Gopher bioturbation: field evidence for non-linear hillslope diffusion. Earth Surface Processes and Landforms, 25, 1419-1428.

Gabet, E. J., Perron, J. T., \& Johnson, D. L. (2014). Biotic origin for Mima mounds supported by numerical modeling. Geomorphology, 206, 58-66.

Gabet, E. J., Reichman, O. J., \& Seabloom, E. W. (2003). The effects of bioturbation on soil processes and sediment transport. Annual Review of Earth and Planetary Sciences, 31, 249-273.

Garkaklis, M. J., Bradley, J. S., \& Wooller, R. D. (2004). Digging and soil turnover by a mycophagous marsupial. Journal of Arid Environments, 56, 569-578.

Hall, K., \& Lamont, N. (2003). Zoogeomorphology in the Alpine: some observations on abiotic-biotic interactions. Geomorphology, 55, 219-234.

Hansell, M. H. (1993). The ecological impact of animal nests and burrows. Functional Ecology, 7, 5-12.

Hansen, R. M., \& Morris, M. J. (1968). Movement of rocks by northern pocket gophers. Journal of Mammalogy, 49, 391-399.

Hastings, A., Byers, J. E., Crooks, J. A., Cuddington, K., Jones, C. G., Lambrinos, J. G., . . .Wilson, W. G. (2007). Ecosystem engineering in space and time. Ecology Letters, 10, 153-164. 
Hofer, H. (1988). Variation in resource presence, utilization and reproductive success within a population of European Badgers (Meles meles). Mammal Review, 18, 2536.

Hole, F. D. (1981). Effects of animals on soil. Geoderma, 25, 75-112.

Huntly, N., \& Reichman, O. J. (1994). Effects of subterranean mammalian herbivores on vegetation. Journal of Mammalogy, 75, 852-859.

James, A. I., Eldridge, D. J., \& Moseby, K. E. (2010). Foraging pits, litter and plant germination in an arid shrubland. Journal of Arid Environments, 74, 516-520.

Johnson, D. L., \& Horwath Burnham, J. L. (2012). Introduction: Overview of concepts, definitions, and principles of soil mound studies. In J. L. Horwath Burnham \& D. L. Johnson (Eds.) Mima Mounds - The case for polygenesis and bioturbation (pp. 120). USA: The Geological Society of America.

Johnson, D. D. P., Jetz, W., \& Macdonald, D. W. (2002). Environmental correlates of badger social spacing across Europe. Journal of Biogeography, 29, 411-425.

Jones, C. G. (2012). Ecosystem engineers and geomorphological signatures in landscapes. Geomorphology, 157-158, 75-87.

Jones, C. G., Lawton, J. H., \& Shachak, M. (1994). Organisms as ecosystem engineers. Oikos, 69, 373-386.

Jones, C. G., Lawton, J. H., \& Shachak, M. (1997). Positive and negative effects of organisms as physical ecosystem engineers. Ecology, 78, 1946-1957.

Kaneko, Y., Newman, C., Buesching, C. D., \& Macdonald, D. W. (2010). Variations in badger (Meles meles) sett microclimate: Differential cub survival between main and subsidiary setts, with implications for artificial sett construction. International Journal of Ecology, Article ID 859586. doi:10.1155/2010/859586.

Kinlaw, A. (1999). A review of burrowing by semi-fossorial vertebrates in arid environments. Journal of Arid Environments, 41, 127-145. 
691 Kinlaw, A., \& Grasmueck, M. (2012). Evidence for and geomorphologic consequences of a reptilian ecosystem engineer: The burrowing cascade initiated by the Gopher Tortoise. Geomorphology, 157-158, 108-121.

Kruuk, H. (1978a). Spatial organization and territorial behaviour of the European badger Meles meles. Journal of Zoology, 184, 1-19.

Kruuk, H. (1978b). Foraging and spatial organisation of the European badger, Meles meles L. Behavioral Ecology and Sociobiology, 4, 75-89.

Kruuk, H. (1989). The Social Badger. Oxford: Oxford University Press.

Kurek, P., Kapusta, P., \& Holeksa, J. (2014). Burrowing by badgers (Meles meles) and foxes (Vulpes vulpes) changes soil conditions and vegetation in a European temperate forest. Ecological Research, 29, 1-11.

Löffler, E., \& Margules, C. (1980). Wombats detected from space. Remote Sensing of Environment, 9, 47-56.

Long, C. A., \& Killingley, C. A. (1983). The Badgers of the World. Springfield, Illinois: Charles C. Thomas Publications.

Macdonald, D. W., Mitchelmore, F., \& Bacon, P. J. (1996). Predicting badger sett numbers: evaluating methods in East Sussex. Journal of Biogeography, 23, 649_ 655.

Macdonald, D. W., \& Newman, C. (2002). Population dynamics of badgers (Meles meles) in Oxfordshire, U.K.: numbers, density and cohort life histories, and a possible role of climate change in population growth. Journal of Zoology, 256, 121-138.

Macdonald, D. W., Newman, C., Buesching, C. D., \& Nouvellet, P. (2010). Are badgers 'Under The Weather'? Direct and indirect impacts of climate variation on European badger (Meles meles) population dynamics. Global Change Biology, 16, 29132922. 
Macdonald, D. W., Newman, C., Dean, J., Buesching, C. D., \& Johnson, P. J. (2004). The distribution of Eurasian badger, Meles meles, setts in a high-density area: Field observations contradict the sett dispersion hypothesis. Oikos, 106, 295-307.

Macdonald, D. W., Newman, C., Nouvellet, P. M., \& Buesching, C. D. (2009). An analysis of Eurasian badger (Meles meles) population dynamics: Implications for regulatory mechanisms. Journal of Mammalogy, 90, 1392-1403.

Maestre, F. T., Quero, J. L., Gotelli, N. J., Escudero, A., Ochoa, V., Delgado-Baquerizo, M., .. Zaady, E. (2012). Plant species richness and ecosystem multifunctionality in global drylands. Science, 335, 214-218.

Martin, B. G. (2003). The role of small ground-foraging mammals in topsoil health and biodiversity: Implications to management and restoration. Ecological Management \& Restoration, 4, 114-119.

Meadows, A. (1991). Burrowing and burrowing animals: An overview. In P. S. Meadows \& A. Meadows (Eds.), The Environmental Impact of Burrowing Animals and Animal Burrows (pp. 1-13). Zoological Society of London Symposia 63. Oxford: Clarendon Press.

Meadows, P. S., \& Meadows, A. (Eds.). (1991). The Environmental Impact of Burrowing Animals and Animal Burrows. Zoological Society of London Symposia 63. Oxford: Clarendon Press.

Naylor, L. A., Viles, H. A., Carter, N. E. A. (2002). Biogeomorphology revisited: Looking towards the future. Geomorphology, 47, 3-14.

Neal, E. G. (1977). Badgers. Poole, Dorset: Blanford Press.

Neal, E. G., \& Roper, T. J. (1991). The environmental impact of badgers (Meles meles) and their setts. In P. S. Meadows \& A. Meadows (Eds.), The Environmental Impact of Burrowing Animals and Animal Burrows (pp. 89-106). Zoological Society of London Symposia 63. Oxford: Clarendon Press. 
Neal, E. G., \& Cheeseman, C. L. (1996) Badgers. London: Poyser.

Neave, M., \& Abrahams, A. D. (2001). Impact of small mammal disturbances on sediment yield from grassland and shrubland ecosystems in the Chihuahuan Desert. CATENA, 44, 285-303.

Noonan, M. J., Markham, A., Newman, C., Trigoni, N., Buesching C. D., Ellwood, S. A., \& Macdonald, D. W. (2014). Climate and the Individual: Inter-Annual variation in the autumnal activity of the European Badger (Meles meles). PLoS ONE, 9, e83156.

Nouvellet, P., Newman, C., Buesching, C. D., \& Macdonald, D. W. (2013). A multi-metric approach to investigate the effects of weather conditions on the demographic of a terrestrial mammal, the European badger (Meles meles). PLoS ONE, 8, e68116.

Obidziński, A., Pabjanek, P., \& Mędrzycki, P. (2013). Determinants of badger Meles meles sett location in Białowieża Primeval Forest, northeastern Poland. Wildlife Biology, 19, 48-68.

Price, L. W. (1971). Geomorphic effect of the Arctic Ground Squirrel in an alpine environment. Geografiska Annaler. Series A, Physical Geography, 53, 100-106.

Prugh, L. R., \& Brashares, J. S. (2012). Partitioning the effects of an ecosystem engineer: kangaroo rats control community structure via multiple pathways. Journal of Animal Ecology, 81, 667-678.

Reichman, O. J., \& Smith, S. C. (1990). Burrows and burrowing behavior by mammals. In H. H. Genoways (Ed.), Current Mammalogy. (pp. 197-244). London: Plenum Press.

Reinhardt, L., Jermlmack, D., Cardinale, B. J., Vanacker, V., \& Wright, J. P. (2010). Dynamic interactions of life and its landscape: Feedbacks at the interface of geomorphology and ecology. Earth Surface Processes and Landforms, 35, 78-101.

Revilla, E., Palomares, F., \& Fernández, N. (2001). Characteristics, location and selection of diurnal resting dens by Eurasian badgers (Meles meles) in a low density area. Journal of Zoology, 255, 291-299. 
Roper, T. J. (1992a). The structure and function of badger setts. Journal of Zoology, 227, 691-694.

Roper, T. J. (1992b). Badger Meles meles setts-architecture, internal environment and function. Mammal Review, 22, 43-53.

Roper, T. J., Ostler, J. R., Schmid, T. K., \& Christian, S. F. (2001). Sett use in European badgers Meles meles. Behaviour, 138, 173-187.

Rutin, J. (1992). Geomorphic activity of rabbits on a coastal sand dune, De Blink dunes, the Netherlands. Earth Surface Processes and Landforms, 17, 85-94.

Schiffers, K., Teal, L. R., Travis, J. M. J., \& Solan, M. (2011). An open source simulation model for soil and sediment bioturbation. PLOS ONE, 6, e28028.

Smits, C. M. M., Smith, C. A. S., \& Slough, G. B. (1988). Physical characteristics of arctic fox (Alopex algopus) dens in northern Yukon Territory, Canada. Arctic, 41, 12-16.

Stewart, P. D., Bonesi, L., \& Macdonald, D. W. (1999). Individual differences in den maintenance effort in a communally dwelling mammal: the Eurasian badger. Animal Behaviour, 57, 153-161.

Thorn, C. E. (1978). A preliminary assessment of the geomorphic role of pocket gophers in the alpine zone of the Colorado Front Range. Geografiska Annaler. Series A, Physical Geography, 60, 181-187.

Thornton, P. S. (1988). Density and distribution of Badgers in south-west England-a predictive model. Mammal Review, 18, 11-23.

Viles, H. A. (Ed.). (1988). Biogeomorphology. Oxford: Basil Blackwell.

Viles, H. A. (2012). Microbial geomorphology: A neglected link between life and landscape. Geomorphology, 157-158, 6-16.

Voslamber, B., \& Veen, A. W. L. (1985). Digging by badgers and rabbits on some wooded slopes in Belgium. Earth Surface Processes and Landforms, 10, 79-82. 
Wessel, A. T. (1988). On using the effective contact angle and the water drop penetration time for classification of water repellency in dune soils. Earth Surface Processes and Landforms, 13, 555-561.

Whitford, W. G., \& Kay, F. R. (1999). Biopedturbation by mammals in deserts: A review. Journal of Arid Environments, 41, 203-230.

Wilkinson, M. T., Richards, P. J., \& Humphreys, G. S. (2009). Breaking ground: Pedological, geological, and ecological implications of soil bioturbation. EarthScience Reviews, 97, 257-272.

Woodroffe, R., \& Macdonald, D. W. (1993). Badger sociality: Models of spatial grouping. Zoological Society of London Symposia 65, 145-169.

Wright, J. P., \& Jones, C. G. (2006). The concept of organisms as ecosystem engineers ten years on: Progress, limitations, and challenges. BioScience, 56, 203-209.

Yair, A. (1995). Short and long term effects of bioturbation on soil erosion, water resources and soil development in an arid environment. Geomorphology, 13, 87-99.

Yair, A., \& Rutin, J. (1981). Some aspects of the regional variation in the amount of available sediment produced by isopods and porcupines, Northern Negev, Israel. Earth Surface Processes and Landforms, 6, 221-234.

Yoo, K., Amundson, R., Heimsath, A. M., \& Dietrich, W. E. (2005). Process-based model linking pocket gopher (Thomomys bottae) activity to sediment transport and soil thickness. Geology, 33, 917-920.

Zaitlin, B., \& Hayashi, M. (2012). Interactions between soil biota and the effects on geomorphological features. Geomorphology, 157-158, 142-152. 


\begin{tabular}{ll}
\hline Sett Variable & Description \\
\hline Sett age & $\begin{array}{l}\text { Minimum number of years a sett has existed (31 years is the } \\
\text { minimum age for setts identified in Kruuk 1978a; 18 years for } \\
\text { setts present at the first capture (1987); absolute age of setts } \\
<18 \text { years is known from trapping records). }\end{array}$ \\
Independence age & $\begin{array}{l}\text { Minimum number of years since a sett has been socially } \\
\text { independent from other setts, having its own established } \\
\text { territory. }\end{array}$ \\
Unique residency & $\begin{array}{l}\text { Total minimum number of unique adult badgers ever trapped } \\
\text { at a sett since 1987. }\end{array}$ \\
Males & $\begin{array}{l}\text { Minimum total number of unique adult males ever trapped at } \\
\text { a sett since 1987. }\end{array}$ \\
Females & $\begin{array}{l}\text { Minimum total number of unique adult females ever trapped } \\
\text { at a sett since 1987. }\end{array}$ \\
Sex ratio & $\begin{array}{l}\text { Proportion of adult females to adult males comprising total } \\
\text { unique residency. }\end{array}$ \\
Sett fecundity & $\begin{array}{l}\text { Total number of unique cubs ever trapped at a sett. } \\
\text { Female fecundity }\end{array}$ \\
Mxcavation years $\left(X_{y r}\right)$ & $\begin{array}{l}\text { Mean number of cubs per unique female resident of a sett. } \\
\text { Cumulative total years' residency of all unique badgers. }\end{array}$ \\
Fidelity & $\begin{array}{l}\text { Mean number of years each unique adult remained resident } \\
\text { at a sett. }\end{array}$
\end{tabular}

Table 1. Sett variables determined for every member of the badger population recorded in the Wytham Trapping Database as of 2004 (raw data supplied by WildCRU, Department of Zoology, University of Oxford). 


\begin{tabular}{|c|c|c|c|c|c|c|c|c|c|c|}
\hline Sett ID & $\begin{array}{r}\text { Minimum } \\
\text { age (yrs) }\end{array}$ & $\begin{array}{r}\text { Surface } \\
\operatorname{area}^{a}\left(m^{3}\right) \\
\end{array}$ & $\begin{array}{r}\text { Entrance } \\
\text { holes }\end{array}$ & $\begin{array}{r}\text { Unique } \\
\text { residency }\end{array}$ & $\begin{array}{r}\text { Excavation } \\
\text { years }\left(X_{y r}\right)\end{array}$ & $\begin{array}{r}\text { Sex ratio } \\
\text { (f:m) }\end{array}$ & $\begin{array}{r}\text { Fidelity } \\
(y r s) \\
\end{array}$ & $\begin{array}{r}\text { Sett } \\
\text { fecundity }\end{array}$ & $\begin{array}{r}\text { Female } \\
\text { fecundity }\end{array}$ & $\begin{array}{r}\text { Excavation } \\
\text { volume }^{b}\left(\mathrm{~m}^{3}\right)\end{array}$ \\
\hline BB & 31 & $300^{*}$ & 10 & 54 & 98 & 1.33 & 1.81 & 21 & 0.50 & 8.9 \\
\hline BP & 18 & 80 & 5 & 38 & 98 & 0.96 & 2.58 & 10 & 0.20 & 2.3 \\
\hline $\mathrm{CH}$ & 31 & 147 & 12 & 80 & 189 & 1.25 & 2.36 & 33 & 0.39 & 4.3 \\
\hline CLO & 7 & 55 & 3 & 21 & 39 & 0.56 & 1.86 & 6 & 0.24 & 1.5 \\
\hline FB & 10 & 225 & 9 & 28 & 69 & 0.77 & 2.46 & 17 & 0.44 & 6.6 \\
\hline GATES & 6 & 32 & 9 & 13 & 22 & 1.20 & 1.69 & 6 & 0.60 & 0.8 \\
\hline $\mathrm{GO}$ & 31 & 930 & 26 & 62 & 142 & 0.46 & 2.29 & 52 & 0.54 & 27.8 \\
\hline GOA & 6 & 20 & 2 & 6 & 7 & 0.40 & 1.17 & 1 & 0.20 & 0.5 \\
\hline GW & 18 & 218 & 5 & 42 & 82 & 1.05 & 1.95 & 10 & 0.25 & 6.4 \\
\hline $\mathrm{HC}$ & 18 & 128 & 11 & 50 & 117 & 1.13 & 2.34 & 24 & 0.44 & 3.7 \\
\hline HCFO & 11 & 24 & 4 & 17 & 23 & 0.64 & 1.35 & 8 & 0.57 & 0.6 \\
\hline $\mathrm{HCMO}$ & 8 & 12 & 3 & 6 & 6 & 5.00 & 1.00 & 1 & 1.00 & 0.2 \\
\hline HCT & 2 & 37 & 2 & 5 & 5 & 0.67 & 1.00 & 0 & 0.00 & 1.0 \\
\hline $\mathrm{HH}$ & 18 & $136^{*}$ & 9 & 36 & 71 & 1.22 & 1.97 & 8 & 0.25 & 3.9 \\
\hline $\mathrm{JH}$ & 18 & 189 & 10 & 39 & 121 & 1.47 & 3.10 & 18 & 0.37 & 5.5 \\
\hline $\mathrm{JkBr}$ & 8 & $400^{*}$ & 8 & 5 & 7 & 0.75 & 1.40 & 4 & 1.00 & 11.9 \\
\hline $\mathrm{KH}$ & 10 & 144 & 10 & 28 & 52 & 0.73 & 1.86 & 5 & 0.17 & 4.2 \\
\hline M2 & 17 & 86 & 5 & 22 & 41 & 0.95 & 1.86 & 18 & 0.86 & 2.4 \\
\hline $\mathrm{McBr}$ & 12 & 248 & 10 & 10 & 17 & 0.42 & 1.70 & 19 & 1.58 & 7.3 \\
\hline MT & 31 & 744 & 29 & 19 & 30 & 0.88 & 1.58 & 26 & 1.63 & 22.2 \\
\hline 01 & 18 & 35 & 4 & 38 & 59 & 1.27 & 1.55 & 10 & 0.38 & 0.9 \\
\hline$P$ & 18 & 546 & 10 & 67 & 197 & 0.70 & 2.94 & 41 & 0.35 & 16.2 \\
\hline $\mathrm{PO}$ & 10 & 200 & 4 & 41 & 104 & 1.08 & 2.54 & 17 & 0.34 & 5.9 \\
\hline $\mathrm{RC}$ & 18 & 260 & 22 & 47 & 121 & 1.15 & 2.57 & 18 & 0.31 & 7.7 \\
\hline $\mathrm{RCO}$ & 10 & 48 & 7 & 32 & 32 & 0.45 & 1.00 & 5 & 0.23 & 1.3 \\
\hline $\mathrm{SH}$ & 18 & 300 & n.d. & 60 & 167 & 1.09 & 2.78 & 25 & 0.31 & 8.9 \\
\hline TC & 31 & $150^{*}$ & 10 & 48 & 102 & 0.55 & 2.13 & 38 & 0.58 & 4.4 \\
\hline TCB & 5 & $40^{*}$ & 4 & 15 & 23 & 0.44 & 1.53 & 1 & 0.06 & 1.1 \\
\hline UF & 17 & 100 & 5 & 22 & 28 & 0.75 & 1.27 & 22 & 1.38 & 2.9 \\
\hline
\end{tabular}

${ }^{a}$ minimum surface area of disturbed soil ( ${ }^{*}$ indicates partially-obstructed setts for which surface area was visually estimated) ${ }^{b}$ volume estimated from surface area data using regression modelling (eq. 2)

Table 2. Sett variables determined for visited setts $(n=29$, data for the other 35 named setts are not shown here). Surface area and number of entrance hole were determined in the field (in 2005); excavation volumes were estimated using regression modelling (see text); all other parameters are derived from the Wytham Trapping Database (see Table 1). Surveyed and reconstructed setts (Mac Bracken and Pasticks Outlier) are shaded. n.d. indicates no available data. 


\begin{tabular}{|c|c|c|c|c|}
\hline Bioconstruction & $\begin{array}{r}\text { Location of } \\
\text { study }\end{array}$ & $\begin{array}{r}\text { Surface } \\
\text { area }\left(m^{2}\right)\end{array}$ & $\begin{array}{r}\text { Height } \\
\text { (m) }\end{array}$ & Reference \\
\hline \multirow{2}{*}{$\begin{array}{l}\text { Eurasian badger setts } \\
\text { (Meles meles) }\end{array}$} & $\begin{array}{l}\text { Central } \\
\text { southern } \\
\text { England }\end{array}$ & $12-930$ & $0.2-2.0$ & This study \\
\hline & Belgium & $14.7^{a}$ & n.d. & $\begin{array}{r}\text { Voslamber \& Veen, } \\
1985\end{array}$ \\
\hline $\begin{array}{l}\text { European rabbit } \\
\text { warrens } \\
\text { (Oryctolagus cuniculus) }\end{array}$ & $\begin{array}{l}\text { Southern } \\
\text { Australia }\end{array}$ & $200^{b}$ & $0.1-0.2$ & Eldridge \& Myers, 2001 \\
\hline $\begin{array}{l}\text { Wombat warrens } \\
\text { (Lasiorhinus latifrons) }\end{array}$ & $\begin{array}{l}\text { Southern } \\
\text { Australia }\end{array}$ & $314-707^{c}$ & $0.5-1.0$ & $\begin{array}{r}\text { Löffler \& Margules, } \\
1980\end{array}$ \\
\hline $\begin{array}{l}\text { Arctic fox dens } \\
\text { (Alopex lagopus) }\end{array}$ & $\begin{array}{r}\text { Northwestrn } \\
\text { Canada }\end{array}$ & $123-130$ & $2.1-4.5$ & $\begin{array}{r}\text { Smits, Smith \& Slough, } \\
1988\end{array}$ \\
\hline $\begin{array}{l}\text { Giant Kangaroo Rat } \\
\text { mounds } \\
\text { (Dipodomys ingens) }\end{array}$ & $\begin{array}{r}\text { Western } \\
\text { USA }\end{array}$ & $38-79^{d}$ & $0.5-2.0^{e}$ & $\begin{array}{r}\text { Prugh \& Brashares, } \\
2012\end{array}$ \\
\hline $\begin{array}{l}\text { Prairie dog mounds } \\
\text { (Cyonmys ludovicianus) }\end{array}$ & $\begin{array}{l}\text { Central } \\
\text { America }\end{array}$ & $4.9^{f}$ & 1 & Cincotta, 1989 \\
\hline $\begin{array}{l}\text { Mima mounds } \\
\text { (assuming pocket } \\
\text { gopher origin, } \\
\text { Geomyidae) }\end{array}$ & $\begin{array}{r}\text { Northwestern } \\
\text { USA }\end{array}$ & $0.8-707^{g}$ & $0.1-2.0$ & $\begin{array}{r}\text { Johnson \& Horwath } \\
\text { Burnham, } 2012\end{array}$ \\
\hline
\end{tabular}

\footnotetext{
aassuming a circular sett planform of $4.32 \mathrm{~m}$ mean diameter

btext description

cassuming a circular mound planform of 20-30 m diameter

dassuming a circular mound planform of 7-10 $\mathrm{m}$ diameter

e based on visual inspection of Plate 1 in Prugh \& Brashares, 2012

fassuming a circular mound planform of $2.5 \mathrm{~m}$ diameter

gassuming a circular mound planform of 1-30 m diameter
}

Table 3. Some indicative dimensions of burrowing animal bioconstructions (n.d. indicates no data). 


\begin{tabular}{|c|c|c|c|c|}
\hline Calculation method & $\begin{array}{r}\text { Per badger } \\
\text { excavation rate } \\
(e), \mathrm{m}^{3} \mathrm{yr}^{-1}\end{array}$ & $\begin{array}{r}\text { Total } \\
\text { excavation } \\
\text { volume for } \\
\text { Wytham } \\
\text { Woods, } \mathrm{m}^{3 a}\end{array}$ & $\begin{array}{r}\text { Local } \\
\text { excavation in } \\
\text { rate (in sett } \\
\text { areas), } \mathrm{m}^{3} \mathrm{yr}^{-1 b}\end{array}$ & $\begin{array}{r}\text { Spatially- } \\
\text { averaged } \\
\text { sediment } \\
\text { production, } \\
\mathrm{g} \mathrm{m}^{-2} \mathrm{yr}^{-1 c}\end{array}$ \\
\hline Regression modelling & $0.21^{d}$ & 304.4 & $6.7-9.8$ & $1.4-2.1$ \\
\hline $\begin{array}{l}\text { Extrapolation from } \\
\text { Pasticks Outlier (PO) } \\
\text { sett ' } e \text { ' }\end{array}$ & 0.19 & 601.4 & $13.1-19.4$ & $2.8-4.1$ \\
\hline $\begin{array}{l}\text { Extrapolation from } \\
\text { Mac Bracken (MB) sett } \\
\text { ' } e \text { ' }\end{array}$ & 1.53 & $4,842.5$ & $113.3-156.2$ & $24.1-33.2$ \\
\hline
\end{tabular}

afor 64 named setts, as of 2004

bannual excavation rate over a minimum total sett surface area of $1.15 \mathrm{ha}$; lower and upper estimates exclude and include setts of unknown age (> 31 years), respectively, based on Kruuk 1978a ${ }^{c}$ spatially-averaged rate based on a total area for Wytham Woods of 424 ha

'mean value of 'e' for all setts, derived from regression model estimates of volume in each case

Table 4. Badger mound excavation volumes and rates estimated from two different methods: (1) regression modelling using surface area, and (2) extrapolation from individual badger digging rates, $e$, determined for two different setts. 


\begin{tabular}{lrr}
\hline & \multicolumn{2}{c}{ Estimated Volume of Soil $\left(\mathbf{m}^{\mathbf{3}}\right)$} \\
\cline { 2 - 3 } & Regression modelling & 3D modelling \\
\hline Mac Bracken sett (MB) & 7.3 & 26.0 \\
Pasticks Outlier sett (PO) & 5.9 & 19.3 \\
\hline
\end{tabular}

Table 5. Comparison of sett excavation volumes derived for two setts using: (1) regression models based on surface area and ecological sett data, and (2) GIS reconstructions from field survey data and cut-fill analysis. 


\begin{tabular}{lrrrr}
\hline Source & d.f. & MS & F & P \\
Sett patch $(n=3)$ & 3 & 35.52 & 0.00 & 0.999 \\
Cover type $(n=4)$ & 8 & 13799.77 & 49.08 & $<0.000$ \\
Residuals & 228 & 281.16 & - & - \\
Total & 239 & - & - & - \\
\hline
\end{tabular}

Cochran's test for heterogeneity $=0.159$, not significant

Table 6. Analysis of variance for surface cover (bare soil, litter, and vegetation) nested in sett surface patch (spoil mound top, spoil mound flank, inter-mound area, control), $n=20$ per patch, see Figure 6. 


\begin{tabular}{lrrrr}
\hline Source & d.f. & MS & F & P \\
Sett patch $(n=4)$ & 3 & 5.401 & 124.34 & $<0.000$ \\
Residuals & 116 & 0.0434 & - & - \\
Total & 119 & - & - & - \\
\hline
\end{tabular}

Data square-root transformed; Cochran's test for heterogeneity $=0.386$, not significant

Table 7. Analysis of variance for soil penetration strength between sett surface patches (fresh spoil, older spoil, badger path, control), $n=30$ per patch, see Figure 8. 


\section{Figure captions}

Figure 1. A typical spoil mound of the Eurasian Badger (Meles meles). Multiple mounds coalesce to form larger sett surface complexes.

Figure 2. The distribution of named badger setts at Wytham Woods, Oxfordshire (2004 data supplied by WildCRU, Department of Zoology, University of Oxford). Location of Calcarious Grit Sand layer in which the majority of setts are dug is also shown, digitized from Kruuk 1978a. Reconstructed setts (Mac Bracken and Pastics Outlier) are indicated. Figure 3. Features of badger bioturbation in Wytham Woods: (a) characteristic sandy spoil, (b) spoil with stony Coral Rag incorporated, (c) topographic depression resulting from burrow entrance collapse, (d) bedding material recently cleared from a burrow entrance, (e) litter accumulation in a badger dig, (f) well-defined mound/inter-mound boundary illustrating shedding of material from compact mound slopes, (g) vegetation growing on a badger mound, (h) size-sorting of stones on a sett slope.

Figure 4. Minimum population size of badgers (solid line) and number of newly constructed setts (dashed line) between 1987 and 2004. A statistically significant correlation exists factoring in a 3-year lag $\left(\mathrm{R}^{2}=0.67, p=0.006\right)$.

Figure 5. Three-dimensional models of: (a) Mac Bracken Sett (MB) and; (b) Pasticks Outlier sett (PO) reconstructed from field-survey data using GIS. Pre-disturbance (top), sett complex (middle) and cut-fill (bottom) surfaces shown. Planform maps $(0.1 \mathrm{~m}$ interpolated contours) and pre- and post-disturbance cross-section profiles also shown (color versions available online).

Figure 6. Mean (+ SD, $n=20$ ) surface cover (\%) of bare soil, litter, vegetation, and stones for different sett surface patches and control areas.

Figure 7. Relative proportions of mud, sand, and gravel (\%) for soil samples $(<5 \mathrm{~cm}$ depth, $n=5$ ) for different sett surface patches and control areas. 
Figure 8. Mean soil penetration strength (+ SD, $n=30$ ) in different sett patches and control soils.

Figure 9. Wet and dry aggregate stability for samples taken from different sett surface patches and control areas ("breakdown time for dry fresh spoil was instantaneous). 